\title{
International Political Economy (IPE) meets International Political Sociology (IPS)
}

International Relations 2019, Vol. 33(4) 586-619

(C) The Author(s) 2019

Article reuse guidelines: sagepub.com/journals-permissions DOI: | 0.1 I77/0047| I78|9885|6| journals.sagepub.com/home/ire

(3)AGE

\author{
Jean-Christophe Graz
}

University of Lausanne

\section{Oliver Kessler}

University of Erfurt

\section{Rahel Kunz}

University of Lausanne

\begin{abstract}
This forum opens a debate that is long overdue: for far too long, the fields of international political sociology (IPS) and international political economy (IPE) have been standing apart. Discussions take place in different conference sections, in different networks that publish in different journals. Yet, this divide is surprising given that the two fields share similar trajectories, theoretical concerns, problématiques, and conceptual challenges. This forum starts exploring this shared terrain: we believe that there is no a priori reason to separate the sociocultural, the political and the economic when we aim at making sense of the world in any meaningful way. We propose that bridging the IPE-IPS divide has tremendous potential for the development of a sociopolitical economy analysis that, we believe, has two benefits. First, it allows for the opening of new empirical terrains or deepening and widening existing ones. Second, bringing IPE/S back together creates reflexive spaces for more holistic, embodied and contextualised conceptual innovation. The contributors to this forum show each in their own way such empirical and conceptual added value of moving beyond the IPE and IPS divide in order to develop what we call here a socio-political economy of the globe. They focus on various issues, such as the transformation of capitalism from an oil- to a data-dependent accumulation regime with the rising of the socalled 'digital age' (Chenou); the profound social, economic and political transformation triggered by urbanisation in the development world (Elias, Rethel and Tilley); emerging global risks and
\end{abstract}

\section{Corresponding author:}

Rahel Kunz, University of Lausanne, 1015 Lausanne, Switzerland.

Email: rahel.kunz@unil.ch 
the neglected role of the insurance industry (Lobo-Guerrero); regional development-security nexuses (Lopez Lucia); and business power in climate change diplomacy (Moussu).

\section{Keywords}

climate diplomacy, development-security nexus, digital age, international political economy, international political sociology, sociopolitical economy of the globe, urbanisation, climate diplomacy

\section{Introduction}

This forum is intended to open a discussion that is long overdue: for far too long, the fields of international political sociology (IPS) and international political economy (IPE) have been standing too far apart. Discussions take place in different conference sections, in different networks that publish in different journals. IPS scholarship still often focuses mostly on security issues while economic phenomena and events get less attention. At the same time, IPE research - at least within the confines of what we shall call here heterodox scholarship for lack of a better term - is increasingly obsessed by the intricacies of monetary and financial issues, with much less interest in security and the social. ${ }^{1}$ Perhaps more importantly, not only IPS and IPE tend to show to each other a mutual neglect, but they start to observe themselves with increasing suspicion. Some IPS scholars, for example, tend to discard any critical prospects for IPE. The assumption recently made in an IPS volume that IPE is confined to failed attempts at reframing international relations from within would serve as an example. ${ }^{2}$

This celebrated divide comes as a surprise as even a cursory look at dedicated journals shows that there are similar theoretical concerns, similar problématiques (e.g. digitalisation, inequalities, crisis, colonial legacies) and similar conceptual challenges (e.g. power, discourse, practices). In both fields, we see references to the same social theorists and the use of concepts such as (neoliberal) governmentality, actor-network or 'critique'. We see the same turn to questions of hierarchy and expertise, the same interest in the construction of (global) social spaces and temporalities, and the same critique of rational approaches to the study of world politics. ${ }^{3}$

So instead of standing apart, we propose that it is more productive to start exploring their shared terrain: if politics is related to the construction of spaces, temporalities or identities, then IPS without the global economy is incomplete just as IPE is blind without an interest in the social. Take standards as an example. Standards are usually taken to be technical devices that regulate practices within a given space. Yet a closer look at the importance ascribed to technical specifications in the globalisation of goods and services shows that it reflects a non-conventional form of power. Standards shape and constitute spaces and the access to them. Governing through standards thus implies an ambiguous re-articulation of governance with much overlap between voluntary specifications set by standard-setting bodies and their use in public regulation. ${ }^{4}$ Or consider the 'financial(ised) subject', which has recently become a major figure in the context of the literature on neoliberalism, finance and development. This concept has been used for example to analyse the implications of the 'financialisation of remittances' 5 The global financial inclusion agenda increasingly draws on remittances to provide unbanked 
people with access to financial services in order to improve household welfare, increase economic growth, and reduce gender and income inequalities. In this process, remittances have become linked to financial education, services and innovation to promote a 'culture of savings' in socioculturally and gender-specific ways. ${ }^{6}$ Prima facie, it does not make sense to separate the financial(ised) subject into an IPS or IPE 'object' and attempts to do so tell us more about the disciplinary confines of International Relations (IR) than about the 'object' we are trying to understand. Analysing the financial(ised) subject beyond this divide allows for a broader and more holistic understanding of its constitution, the context of its emergence and its broader socio-political implications.

While we see references to the economy in IPS and the social in IPE, something like a socio-political economy of the globe is still lacking. ${ }^{7}$ This is quite surprising for three reasons. First, given that both IPS and IPE started as projects that countered the disciplinary confines of IR, it is almost ironic that both reproduce these confines and use techniques of 'othering'. A socio-political economy approach hence seems to be quite natural when we take their 'inter-disciplinary' critiques seriously. Second, such an approach promises to develop better explanations of world political processes as unproductive disciplinary boundaries are left behind. Possibilities for combining concepts such as the 'international', the 'political', the 'social' and the 'economy' cannot just get away with the foundational dimensions each of those concepts stands for. They reflect distinct phenomena, antagonistic principles and historically constituted practices that shaped modern subjects, politics and material life across sovereign spaces over several centuries. Yet, as Walker points out regarding the three concepts of international, political and social, there is 'some kind of unity among heterogeneous phenomena', even if the need for redrawing more fluid boundaries between them requires embracing 'distinctions and exclusions of many kinds' ${ }^{8}$ Moreover, such a move helps viewing the global as a sui generis category, rather than an epiphenomenon resulting from recent transformations of the international system. In the same way as Bartelson views the global as 'a social fact in its own right, whose meaning and function ought to be analysed without any commitment as to its ontological status', a socio-political economy of the globe provides ways to connect the phenomena under study to a level of wholeness likely to change the frame of reference. ${ }^{9}$

Third, on the meta-theoretical level of the disciplinary politics of IR, both IPS and IPE share a certain trajectory: both started as explicitly interdisciplinary projects, with the same intent to broaden the perceived narrow confines of IR. IPE came into existence in the mid 1970s as a reaction to IR being too occupied with security and wars to make sense of events such as the end of Bretton Woods or the rise of OPEC, as the consequences of these events significantly shaped the international order. Apart from merely augmenting the traditional approaches to 'economic phenomena', ${ }^{10}$ IPE explored and challenged the boundaries with heterodox and orthodox economic theory; ${ }^{11}$ it pointed to multinational corporations and financial actors as game changers of the global order. IPS, in a similar trajectory, is an inherently interdisciplinary enterprise. With the demise of 'anarchy' as the key concern of global order, the apparent lack of sociological theory made it difficult to make sense of the emergent agenda of identity formation, ontological security, the everyday and the pluriverse. With an effort to increase 'greater collaboration between sociology and international 
relations', ${ }^{12}$ IPS provides an avenue to fill this gap by exploring the joint terrain of social theory, sociology and IR.

Given these close connections and similar interests, why then is there not more debate between IPE and IPS? One reason might have to do with the 25 years' time difference between them; while IPE fought its way through IR debates in the 1980s with new journals established in the 1990s, IPS followed suite in the 2000s with its flagship journal International Political Sociology - recently celebrating its first decade. Another reason might be the very way the IR discipline is organised, that is, the departmentalisation of our discipline. Both IPE and IPS are connected in their ambiguous relation to the discipline of IR and share a critical engagement with IR as part of broader effort towards what Guillaume and Bilgin ${ }^{13}$ recently described as 'decompartmentalisation', that is, a more unifying and connected view of social sciences. Yet both also have to pursue a strategic withdrawal to create room for manoeuvre in an academic market still characterised by a 'global divide' between a hegemonic, though increasingly insular, American field and the rest, ${ }^{14}$ as well as ever-increasing competitive pressures to find a place in what Seabroke and Young describe as the niche proliferation of IPE research. ${ }^{15}$

Yet, are IPS and IPE just 'cognate fields of study' ${ }^{16}$ Is the divide between IPE and IPS a luxury problem and the dialogue between them an add-on, just another interdisciplinary dialogue? In contrast to Samman and Seabrooke, ${ }^{17}$ who see 'economy' and 'society' as foundational concepts, so much opposed to give good reason for keeping IPE and IPS as separate fields of international studies; we do not think so. Quite to the contrary, we believe that there is no a priori reason to separate the social, the political and the economic when we aim at making sense of the world in any meaningful way. Neither when we deal with apparently 'empirical' objects, the everyday lifeworld, nor when we deal with structural crises and major conflicts. This separation between IPS and IPE is neither a natural given, nor predicated upon a fundamental conceptual opposition, but a discursive construction that is continuously re-enacted. Take for example the global financial crisis. For one, it is almost trivial to highlight that the foreclosure of homes, the dislocation of people and the austerity policies implemented had a massive impact on social relations. We have become accustomed to speak here about youth unemployment rates of 50 per cent, of debt ratios of over 200 per cent and an internal devaluation, which is nothing else than a nicer description of 'impoverishment' on a grand scale. In this sense, a socio-political economic perspective could integrate the analysis of how such 'facts' are transformed into an IPS and/or IPE object - or any other disciplinary form of knowing. We believe that the development of a socio-political economy of the globe would bring out in bold relief the obviously unproductive divides between IPE and IPS and reveal the tremendous potential of moving beyond these divides.

We can draw on scholarship that has similarly challenged established disciplinary and field boundaries with research moving beyond such divides. One example is feminist IR research that has not followed the divisionary developments of the discipline. Most notably, the pioneer work by Cynthia Enloe adopts an approach that includes the political, the economic and the sociocultural, while paying attention to the gendered links between the everyday and the global. ${ }^{18}$ Yet, more recently, feminist IR has also partly been victim of the IPS-IPE divide, which has occurred in various ways, such as in the organisation of specialised panels and publications on feminist IPE and 
feminist security studies. There is a long-standing reflection within feminist IR on the epistemological and political implications of such divides. The recent debate on (re) integrating Feminist Security Studies and Feminist Global Political Economy is a case in point. ${ }^{19}$ Based on a critical appraisal of the politics of constructing distinct fields, it reflects on the historical and epistemological nature of the divide in order to challenge disciplinary boundaries and camp structures. The emergence of Cultural Political Economy and Everyday IPE approaches are another source of inspiration. They emphasise the role of the sociocultural in constituting forms of economic life, and acknowledge the social construction of economic objects and the sociocultural dimensions of economic processes, such as identities, discourses, work cultures and the sociocultural embedding of economic activity. ${ }^{20}$ Similarly, the recent attempt to sketch out a global ecological political economy is not just revisiting standard themes of IPE, such as production, finance or trade, in such a way as to understand them as ecological phenomena, it also highlights that ecological phenomena ought to be understood as continuously reshaped by socio-economic processes. ${ }^{21}$ Social studies of finance provide another good example of a similar move across disciplinary and field boundaries, with established research track records drawing from both ActorNetwork Theory and the Foucauldian tradition. ${ }^{22}$ Finally, a certainly far off the beaten track example is provided by Benjamin Bratton's account of how the shift towards a global digital society substitutes a new form of vertical sovereignty organised across distinct layers for the horizontal model inherited from Westphalia. He draws on political philosophy, architectural theory, computer science and a number of cognate fields to describe such new governing architecture and social processes that 'set the stage for action to unfold' through platforms used as 'standards-based technical-economic system(s) that simultaneously distribute interfaces through their remote coordination and centralizes their integrated control through that same coordination' ${ }^{23}$

What are, then, the prospects of bridging the economic and the social of international politics? We believe such a call is not simply another scholarly debate. Rather, this endeavour should help us pursue a critical stance on the world we live in and engage with. A socio-political economy of the globe could thus make at least two major contributions to forge new avenues of enquiry. First, it can open new empirical terrains or deepen and widen existing ones. A Forum published a few years ago on Brand Aid as a way to explicitly advance IPE/IPS scholarship on North-South relations could be seen as a forerunner. ${ }^{24}$ What Montgomerie ${ }^{25}$ points out regarding critical methods in political and cultural economy applies here as well: we should reclaim the principle of empirical evidence from positivist social science and 'embrace the long-standing tradition of using human experience as (empirical) evidence to uproot deeply established dogma, which only exist to perpetuate established power structures'. Uprooting the IPE-IPS divide allows us to produce richer empirical analyses of international phenomena. Second, by bringing IPE/S back together, a socio-political economy of the globe creates reflexive spaces for more holistic, embodied and contextualised conceptual innovation. It leads towards the construction of new ways of defining relevant objects of study, which, though discrete in their own right, may well be related to issues of epochal change. Theorising beyond this divide demonstrates the importance of taking a processual and relational ontology seriously. 
The contributors to this forum show each in different ways such empirical and conceptual added value of moving beyond the IPE-IPS divide. Empirically, they prompt new research avenues bridging micro-practices and macro-structures as well as integrating voices from the margins to some of the biggest issues of global politics. This includes the transformation of capitalism from an oil- to a data-dependent accumulation regime with the rising of the so-called 'digital age' (Chenou this forum); the profound social, economic and political transformation triggered by urbanisation in the development world (Elias, Rethel and Tilley this forum); emerging global risks and the neglected role of the insurance industry (Lobo-Guerrero this forum); regional development-security nexuses (Lopez Lucia this forum); and business power in climate change diplomacy (Moussu this forum).

Conceptually, each contributor approaches her or his topic from a highly innovative angle that allows them to merge IPE and IPS in their enquiry, such as proposing a fusion of concepts or designing of new analytical tools. In order to make sense of cyberspace, Chenou builds upon the concept of 'socio-technical imaginaries' to combine analyses of power and technology beyond conventional liberal and deterministic accounts. Doing so, he also revisits core concepts of science and technology studies (STS), the political sociology of transnational elites and the analysis of historical structures in IPE. Elias, Rethel and Tilley for their part take a 'granular look' at the transformation of everyday lives to show how gender issues cross the economic and security divide. This approach challenges and strains established field boundaries and the dominant use of concepts such as violence, surveillance and materiality. Doing so, they also lay additional emphasis on knowledge reflexivity and situatedness, demonstrating how feminist IR can avoid the IPE-IPS divide. The contribution of Lobo-Guerrero shows the relevance of studying insurance as a key instrument of governmentality, a concept used by IPS and IPE scholars. He demonstrates that it is only by understanding the intricate technology of insurance that you can understand how it transforms any kind of uncertainty into a commodified instrument of liberal governance. Lopez Lucia shifts studies on non-European regionalism away from conventional security/development agendas towards a distinct focus on what according to her critical IPE and IPS understand best, that is, social processes. This prompts her to chart and incarnate practices beyond a mere appeal for a practice turn or a rehash on the power of performativity. When taken seriously, the concept of socialisation can thus open new avenues in the relations between knowledge, power and governance. Finally, Moussu's bottom-up approach on the politics of business organisations in climate change is not only supported by the methodological potency of network analyses newly called on by IPE and IPS scholars, but also inspired by a meticulous rereading of a social theorist much used and less often read in IPE. Indeed, in discussing Gramsci, he shows that concepts as widely used as class fractions, corporatism, organic intellectuals and hegemony cannot be properly operationalised without understanding the truly social underpinning on which business get organised to overcome its heterogeneity and defend the interest of capital.

\section{Authors' Note}

This forum builds on research presented at several panels seeking to contribute to an enhanced dialogue between IPS and IPE organised in the last 3 years, under the aegis in particular of the 
Joint Groningen-Lausanne-Oslo-Bruxelles-Erfurt (GLOBE) PhD network workshop held in February 2017, the CEEISA-ISA Conference in Ljubljana in 2016, and the Swiss International Political Sociology Working Group at the conference of the Network of French-speaking political associations in Lausanne in 2015. The contributions include a mix of researchers from various contexts and stages of academic career.

\section{Acknowledgements}

The authors would like to thank the anonymous reviewers and editors for their very useful comments on an earlier version of this forum. Special thanks goes to Sylvain Maechler for helping with the formatting and references.

\section{ORCID iDs}

Jean-Christophe Graz (iD https://orcid.org/0000-0002-5583-8332

Rahel Kunz (iD) https://orcid.org/0000-0001-9275-9900

\section{Notes}

1. Taking the flagship journal International Political Sociology as a yardstick, more than half of all research articles published over the 3 years from 2015 to 2017 were closely or loosely related to security (38 out of 69). For its part, IPE's flagship journal Review of International Political Economy mirrors such disproportionate mono-topical focus when it comes to money and finance, with also more than half of research articles published between 2015 and 2017 on that topic (59 out of 113). It should be noted however, that security journals include sometimes IPE related work, be it conventional relationships between trade and conflict or foreign aid: Raynee Gutting and Martin C. Steinwand, 'Donor Fragmentation, Aid Shocks, and Violent Political Conflict', Journal of Conflict Resolution, 61(3), 2017, pp. 643-70; or critical studies that attempt to bring together the theory of political securitisation and the financial securitisation: Andreas Langenohl, 'Securities Markets and Political Securitization: The Case of the Sovereign Debt Crisis in the Eurozone', Security Dialogue, 48(2), 2017, pp. 131-48.

2. Didier Bigo, 'International Political Sociology: Rethinking the International through Dynamics of Power', in Tugba Basaran, Didier Bigo, Emmanuel-Pierre Guittet, and R. B. J. Walker (eds), International Political Sociology: Transversal Lines (London: Routledge, 2017), pp. 28-9.

3. Tugba Basaran, Didier Bigo, Emmanuel-Pierre Guittet, and R. B. J. Walker (eds), International Political Sociology: Transversal Lines (London: Routledge, 2017); Xavier Guillaume and Pinar Bilgin, 'Introduction', in Xavier Guillaume and Pinar Bilgin (eds), Routledge Handbook of International Political Sociology (London: Routledge, 2017), pp. 1-28; Jef Huysmans and Joao Pontes Nogueira, 'Ten Years of IPS: Fracturing IR', International Political Sociology, 10(4), 2016, pp. 299-319; Marc Blyth (ed.), Routledge Handbook of International Political Economy (IPE): IPE as a Global Conversation (London: Routledge, 2009); Nicola Phillips and Catherine Weaver (eds), International Political Economy (London: Routledge, 2010); Melinda Cooper and Martijn Konings, 'Contingency and Foundation: Rethinking Money, Debt, and Finance After the Crisis', South Atlantic Quarterly, 114(2), 2015, pp. 239-50; Timothy M. Shaw, The Palgrave Handbook of Contemporary International Political Economy (London: Palgrave Macmillan, 2019); Alan W Cafruny, Leila Simona Talani, and Gonzalo Pozo Martin (eds), The Palgrave Handbook of Critical International Political Economy (London: Palgrave Macmillan, 2016). 
4. Stefano Ponte, Peter Gibbon, and Jakob Vestergaard (eds), Governing through Standards (Houndmills: Palgrave Macmillan, 2011); Jean-Christophe Graz, The Power of Standards: Hybrid Authority and the Globalisation of Services (Cambridge: Cambridge University Press, 2019); Jean-Christophe Graz, 'Global Corporations and the Governance of Standards', in Andreas Nölke and Christian May (eds), Handbook on Corporations as Global Players (Aldershot: Edward Elgar, 2018), pp. 448-61; JoAnne Yates and Craig N. Murphy, Engineering Rules: Global Standard Setting since 1880 (Baltimore, MD: Johns Hopkins University Press, 2019).

5. Financial remittances are the money that migrant workers send from abroad to their families or communities of origin.

6. Rahel Kunz, 'Remittances', Academic Foresights, 2012, available at: http://www. academic-foresights.com/Remittances.pdf; David Hudson, 'Developing Geographies of Financialisation: Banking the Poor and Remittance Securitisation', Contemporary Politics, 14(3), 2008, pp. 315-33; Vincent Guermond, 'Financialising Remittances: Exploring the Causes and Consequences (I)', Column, 15 July 2014, available at: http:// www.columnf.com/financialising-remittances-exploring-the-causes-and-consequences-i/; Rahel Kunz, 'Gender and Remittances in the Global Political Economy', in Juanita Elias and Adrienne Roberts (eds), Handbook on Gender and IPE (Aldershot: Edward Elgar, 2018), pp. 265-80.

7. Oliver Kessler, 'Sleeping with the Enemy? On Hayek, the Current Economic Crisis and Constructivist Thought in IPE', Review of International Studies, 38(2), 2012, pp. 275-99; Oliver Kessler, 'The Failure of Failure: On Constructivism, the Limits of Critique, and the Socio-Political Economy of Economics', Millennium: Journal of International Studies, 44(3), 2017, pp. 348-69.

8. R. B. J. Walker, 'Only Connect: International, Political, Sociology', in Tugba Basaran, Didier Bigo, Emmanuel-Pierre Guittet, and R. B. J. Walker (eds), International Political Sociology: Transversal Lines (London: Routledge, 2016), p. 17.

9. Jens Bartelson, 'From the International to the Global?' in Andreas Gofas, Inanna HamatiAtaya, and Nicholas Onuf (eds), The SAGE Handbook of the History, Philosophy and Sociology of International Relations (London: SAGE, 2018), p. 41.

10. Robert Gilpin, The Political Economy of International Relations (Princeton, NJ: Princeton University Press, 1987).

11. Ash Amin, Barry Gills, Ronen Palan, and Peter Taylor, 'Editorial: Forum for Heterodox International Political Economy', Review of International Political Economy, 1(1), 1994, pp. $1-12$.

12. Didier Bigo and R.B.J. Walker, 'International, Political, Sociology: Editorial', International Political Sociology, 1(1), 2007, p. 2.

13. Guillaume and Bilgin, 'Introduction', p. 4.

14. Benjamin Cohen, Advanced Introduction To International Political Economy (Aldershot: E.Elgar, 2014).

15. Leonard Seabrooke, and Kevin L. Young, 'The Networks and Niches of International Political Economy', Review of International Political Economy, 24(2), March 2017, pp. 288-331.

16. Guillaume and Bilgin, 'Introduction'.

17. Amin Samman and Leonard Seabrooke, 'International Political Economy', in Xavier Guillaume and Pinar Bilgin (eds), Routledge Handbook of International Political Sociology (London: Routledge, 2017), pp. 46-59.

18. Cynthia Enloe, Bananas, Beaches and Bases: Making Feminist Sense of International Politics, 2nd rev. ed. (Berkeley, CA: University of California Press, 2001); Cynthia Enloe, The Curious Feminist: Searching for Women in a New Age of Empire (Berkeley, CA: 
University of California Press, 2004); Cynthia Enloe, 'The Mundane Matters', International Political Sociology, 5(4), 2011, pp. 447-50.

19. The Critical Perspectives section of the June 2015 issue (edited by Juanita Elias) and the December 2017 forum in Politics \& Gender (edited by Amanda Chisholm and Saskia Stachowitsch).

20. Andrew Sayer, 'For a Critical Cultural Political Economy', Antipode, 33(4), 2001, pp. 687-708; Rob Aitken, 'Performativity, Popular Finance and Security in the Global Political Economy', in Marieke De Goede (ed.), International Political Economy and Poststructural Politics (London: Palgrave Macmillan, 2003), pp. 77-96; Louise Amoore, Globalization Contested: An International Political Economy of Work (Manchester: Manchester University Press, 2002); Paul Langley, The Everyday Life of Global Finance: Saving and Borrowing in Anglo-America (Oxford: Oxford University Press, 2009).

21. Ryan Katz-Rosene and Matthew Paterson, Thinking Ecologically about the Global Political Economy (London: Routledge, 2018).

22. Donald Mackenzie, An Engine, Not a Camera: How Financial Models Shape Markets (Cambridge, MA: MIT Press, 2008); Isabelle Chambost, Marc Lenglet, and Yamina Tadjeddine, The Making of Finance: Perspectives from the Social Sciences (London: Routledge, 2018).

23. Benjamin H. Bratton, The Stack: On Software and Sovereignty (Software Studies) (Cambridge, MA: MIT Press, 2015), pp. 42, 47.

24. Lisa Ann Richey and Stefano Ponte, 'Brand Aid and the International Political Economy and Sociology of North-South Relations: Introduction', International Political Sociology, 7(1), 2013, pp. 92-3.

25. Johnna Montgomerie (ed.), Critical Methods in Political and Cultural Economy (Abingdon: Routledge, 2017), p. 6.

\section{Author biographies}

Jean-Christophe Graz is a Professor of International Relations at the Institut d'Etudes Politiques (IEP) of the University of Lausanne, Switzerland, and co-founder of the Centre d'Histoire Internationale et d'Etudes Politiques de la Mondialisation (CRHIM). He works on regulation issues in global political economy, with a distinct focus on transnational private governance, international standards, service offshoring, and more recently, labour and sustainability standards, risk and uncertainty, and structural transformations of contemporary capitalism. His most recent book is The Power of Standards: Hybrid Authority and the Globalisation of Services (Cambridge University Press, 2019 - Open Access).Email: Jean-Christophe.Graz@unil.ch

Oliver Kessler is a Professor for International Relations at the University of Erfurt. His research focuses on the social theory of risk and uncertainty, interdisciplinary and philosophy and theory of social science and circles current around questions of symbolic orders, triple contingency and authority. His research has been published in journals such as Review of International Studies, Millennium, International Political Sociology, International Theory, Review of International Political Economy, and Leiden Journal of International Law. Email: oliver.kessler@uni-erfurt.de

Rahel Kunz is a Senior Lecturer at the Institut d'Etudes Politiques (IEP) of the University of Lausanne, Switzerland. Her research draws on feminist poststructuralist and postcolonial theories to focus on gender issues in migration and development, and conflict and security issues. She is the author of 'Messy feminist knowledge politics: a double reading of post-conflict gender mainstreaming in Liberia' (forthcoming in International Feminist Journal of Politics) and has published The Political Economy of Global Remittances: Gender, Governmentality and Neoliberalism (Routledge 2011). Email: rahel.kunz@unil.ch 